\title{
Do the Transformation Leadership Style have a Massive Influence on Teacher Job Satisfaction?
}

\author{
Caroline Claudia Anggina Neftyan ${ }^{1}$, Hasan Hariri ${ }^{2}$, Dedy Hermanto Karwan ${ }^{3}$ \\ ${ }^{1}$ Student in Administration of Education,Universitas Lampung, Indonesia \\ ${ }^{2,3}$ Lecturer in Administration of Education,Universitas Lampung, Indonesia
}

\begin{abstract}
In school organizations, principals and teachers have a very important role. This study aims to determine the effect of the principal's transformational leadership style on teacher job satisfaction. The population in this study was a junior high school teacher in Lampung province, Indonesia. The research sample was determined randomly. Data collection uses questionnaires distributed to teachers. Data were analyzed using normality, homogeneity, simple linear regression and T-test. Based on the results of the analysis, it is known that the transformational leadership style does not affect teacher job satisfaction with a $95 \%$ confidence level. Then, based on the results of the T-test, there was no difference in the satisfaction of teacher job between male and female teachers.
\end{abstract}

KEYWORDS: Transformational Leadership Style, Job Satisfaction, Principal, Teachers

\section{INTRODUCTION}

School is an educational organization. Like all organizations, there is someone who is responsible for all affairs of the school and always responsible for management and other activities of school, called the Principal (Ch, Ahmad, Malik, \& Batool, 2017). The principal is an important figure where his behavior is always a concern for students, teachers, and all employees (Musringudin, Akbar, \& Karnati, 2017). The principal is a manager and a leader at school, so he/she is to merely supply the materials needed by the group he/she is leading (Kimathi, 2017; Wachira, GIitumu, \& Mbugua, 2017). The behavior of a principal will show the leadership style he adheres to. Leadership is considered an important element in directing the process. To get things done by other people, principals are asked to guide and lead different activities. Leadership is the ability to influence others (Nazim \& Mahmood, 2018). Leadership style can facilitate change, increase commitment and labor performance, and improve overall organizational performance and approaches in most fields, this raises the awareness that the leadership capacity of educational staff has become increasingly important in educational research (Anderson, 2017).

Leaders are needed in an organization to bring the organization to achieve its goals. The principals' leadership style is the attitude of principal to lead employees to reach the educational goals (Ch et al., 2017; Omeke Faith \& Onah Kenneth, 2011). Leadership style is an important aspect to give effects on school effectiveness, among others are teachers' satisfaction and teachers' job performance (Aunga \& Masare, 2017; Ch et al., 2017; Kimathi, 2017; Nadarasa \& Thuraisingam, 2014). The importance of leadership style is very significant and is related to the job satisfaction of the teachers. Individual consideration, charisma, ideal influence and intellectual stimulation have a positive effect on teacher job satisfaction (Karabina, 2016). In organizations leaders can adopt the appropriate leadership style, and will influence job satisfaction, productivity and commitment of an employee as a result (Voon, Lo, Ngui, \& Ayob, 2011)

Job satisfaction is how content a teacher is with his or her job which culminates in satisfactory interpersonal relations, financial rewards, fringe benefits, training and promotion, decision-making and free channels of communication among others (Nadarasa \& Thuraisingam, 2014; Omeke Faith \& Onah Kenneth, 2011). When teachers are not satisfied with the job, students are the ones who suffer because their academic is likely to deteriorate, because it is widely assumed that school leadership directly influences the effectiveness of teachers and the achievement and motivation out comes of students (Ch et al., 2017; Kimathi, 2017; Nadarasa \& Thuraisingam, 2014; Raziq \& Maulabakhsh, 2015). Principals can therefore encourage effective performance of their teachers by identifying their needs and trying to satisfy or meeting them, also teachers' level of performance involves the skillful control and guidance of teachers in order to achieve the school desired outcomes (Aunga \& Masare, 2017; Shamaki, 2015; Wachira et al., 2017). Job satisfaction leads to recognition, income, promotion and achievement of goals as a result of general feelings fulfilled. This has a good influence on the emotional state of the worker and he has a positive attitude towards his work because satisfied workers tend 


\title{
International Journal of Current Science Research and Review
}

\author{
ISSN: 2581-8341
}

Volume 03 Issue 11 November 2020

DOI: 10.47191/ijcsrr/V3-i11-02, Impact Factor: 6.595

IJCSRR@ 2020

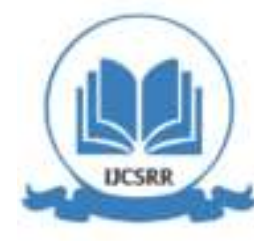

www.ijcsrr.org

to be more loyal, creative and innovative. Job satisfaction is a product of the events and conditions experienced by people in their work (Adeniji, 2011; Nazim \& Mahmood, 2018). In China, it was found that decision making by principals had a positive effect on teacher job satisfaction. Decision making by the principal is a mediation of the leadership style used by the principal with teacher performance satisfaction (Hui et al., 2014; Leykin \& DeRubeis, 2010).

There are some of leadership styles commonly used by previous researchers, but this literature review would be focus on transformational leadership style. Transformational leadership style stimulates and inspires followers to achieve beyond expectation and both have the same vision and objectives they try to achieve. Transformational leadership style could improve their early job experience and gives positive effect on teachers' performance (Aunga \& Masare, 2017; Nyenyembe, Maslowski, Nimrod, \& Peter, 2016). Transformational leadership refers to leadership that increases awareness of organizational members through the creation of collective interests and helps them in their achievement (Hui et al., 2014).

Transformational leader; have integrity, set clear goals, communicate vision clearly, set a good example, expect the best from employees, encourage, inspire and support, recognize work and good people, provide jobs that are able to stimulate and help people to surpass themselves and more focused on the interests and needs of the team (Avolio \& Bass, 2004; Eyal \& Roth, 2011; Wilson, 2017). The focus of transformational leaders in challenging the status quo shows that unexpected performance can produce a higher level of creativity and innovation among followers (Wang, Oh, Courtright, Colbert, \& management, 2011). Transformational leaders have formed a clear image of the future and affected others to implement and share the image despite the resisting and restraining conditions (Mahdinezhad \& Suandi, 2013).

Some research proves that transformational leadership has a positive and strong effect on job satisfaction which shows that transformational leaders are able to transform society and culture within the organization and are important for the success of reform efforts (Al-Omari \& Sharaah, 2012; Amin, Shah, Tatlah, \& Education, 2013; Knab, 2009; Masumoto \& Brown-Welty, 2009; Pepper \& Changing, 2010; Pugh, Fillingim, Blackbourn, \& Thomas, 2011). The study shows that teachers are satisfied if their principal uses a transformational leadership style, this indicates that the transformational leadership style used by the principal becomes an important role in increasing teacher job satisfaction in the school (Gkolia, Belias, \& Koustelios, 2014; Nazim \& Mahmood, 2018). In addition, transformational leadership style is considered to have a positive effect on psychological conditions and is able to enhance innovative behavior possessed by employees (Pieterse, Van Knippenberg, Schippers, \& Stam, 2010).

Transformational leaders can move educators to accomplish progressively and turn out to be more dedicated to their work and the mission of the organization. With the end goal to accomplish this, it is important for authority arrangement projects to improve the transformational capability of people trying to become school leaders. (Eliophotou-Menon \& Ioannou, 2016). Transformational leadership behavior is important for the dimensions of identification and internalization that express deeper commitments (Aydin, Sarier, \& Uysal, 2013). Based on several studies, transformational leadership style is very suitable to be applied in schools.

Based on the many studies that have been conducted, it was found that the leadership style used by principals had positive and significant effect on teacher job satisfaction. These results are the results of research outside Indonesia, then what about the situation in Indonesia? In Indonesia, especially Lampung, there was a study states that at the junior secondary level, the decision-making style used by principals impacts on teacher performance satisfaction (Hariri, Monypenny, \& Prideaux, 2012). Therefore, this study aims to look at the effect obtained from the transformational leadership style by principals on teacher job satisfaction at the senior secondary level. This research is very important because whatever results are obtained from this research, it can be a reference and consideration in determining education policy, especially by the principal. Specifically, we ask two research questions:

1. Do the principal's leadership styles have massive influence on teacher's job satisfaction?

2. What are the influence of the principal's leadership style on teacher performance satisfaction with demographic factors (gender) in the research?

\section{METHOD}

Research on the Indonesian school context was specifically conducted in the province of Lampung. The population in this study were teachers and principals in senior high schools in the province of Lampung. The sample in this research was determined by stratified random sampling technique. This study uses a quantitative approach using three questionnaires as a medium for data collection, the questionnaire regarding the principal's leadership style was based on the theory of Bass and Avolio, questionnaires regarding teacher performance satisfaction by Spector (Spector, 1994), and the demographic factor questionnaire consisting of an individual's gender, age, educational background, teaching subjects and job experience among others (Bolin, 2007), but in this 


\section{International Journal of Current Science Research and Review}

ISSN: 2581-8341

Volume 03 Issue 11 November 2020

DOI: 10.47191/ijesrr/V3-i11-02, Impact Factor: 6.595

IJCSRR@ 2020

www.ijcsrr.org

research will using only gender. Questionnaire is an instrument for collecting data outside the observer's physical range. The questionnaire contains questions that will be used to gather information from respondents about their attitudes, feelings about the problem under study (Kothari, 2004). There are two types of variables used in this study, namely the independent variables consisting of transformational leadership style $(\mathrm{X})$ and the dependent variable is teacher performance satisfaction (Y). Analysis of the relationship between independent variables and the dependent variable using regression analysis through SPSS.

\section{RESULTS AND DISCUSSIONS}

Research has been conducted on senior high school teachers in Bandar Lampung by involving 42 teachers, with 13 male teachers and 29 female teachers. This research is a preliminary study which will then be continued for research on teacher populations spread across Lampung Province, Indonesia. In this study, there was no validity and reliability test because the questionnaire used by the researcher was a questionnaire that had been tested for validity and reliability in measuring the results of the study. The researcher only gave a question to the teacher randomly whether the questionnaire provided could be understood or not. Based on the statement given by the teacher, it is known that the teacher can understand well the questions in the questionnaire provided so that the research can be continued.

This study aims to determine whether there is a major influence between the transformational leadership style possessed by principals on teacher job satisfaction, and then, the researcher want to know whether other factors such as gender can influence teacher job satisfaction. To find out this, based on data obtained through questionnaires, researchers continued the research by analyzing the data obtained using the SPSS program assistance. The first step taken by the researcher is to see whether the data obtained is normally distributed. Based on the results of the calculation of the normality test, it is known that the data obtained are normally distributed and it can be seen on Table 1. Furthermore, based on the homogeneity test results, it is known that the sample comes from a homogeneous population variant with a significance value of $0.599>0.05$ or $\mathrm{H}_{0}$ is accepted. Then to see the relationship and the influence between transformational leadership styles possessed by principals and teacher job satisfaction, researchers conducted a simple linear regression test.

Table 1. The Result of Normality Test

\begin{tabular}{|c|c|c|c|c|c|c|}
\hline & \multicolumn{3}{|c|}{ Kolmogorov-Smirnov ${ }^{\text {a }}$} & \multicolumn{3}{|c|}{ Shapiro-Wilk } \\
\hline & Statistic & df & Sig. & Statistic & df & Sig. \\
\hline $\begin{array}{l}\text { TRANSFORMASIONAL } \\
\text { STEADERSHIP } \\
\text { STYE }\end{array}$ & .123 & 42 & .113 & .966 & 42 & .233 \\
\hline TEACHER JOB SATISFACTION & .081 & 42 & $.200^{*}$ & .977 & 42 & .540 \\
\hline
\end{tabular}

*. This is a lower bound of the true significance.

a. Lilliefors Significance Correction

Table 2. The Result of Homogenity Test ANOVA

\begin{tabular}{llllll}
\hline \multicolumn{2}{l}{ TRANSFORMASIONAL LEADERSHIP STYLE } & & & \\
\hline & Sum of Squares & df & Mean Square & F & Sig. \\
\hline Between Groups & 1031.884 & 23 & 44.865 & .900 & .599 \\
\hline Within Groups & 897.025 & 18 & 49.835 & & \\
\hline Total & 1928.909 & 41 & & & \\
\hline
\end{tabular}

Before conducting a simple liner regression test, a classic assumption test was carried out, namely residual normality test and linearity test. Based on the table 3, it can be seen that the residual value in the research data is normally distributed with a significance value of $0.978>0.05$ and linear in Tabel 4 with a significance value of $0.339>0.05$ and $\mathrm{F}_{\text {value }}<\mathrm{F}_{\text {table }}$ which is $1.231<4,050$, so $\mathrm{H}_{0}$ is accepted. Thus, researchers can carry out simple linear regression tests. 


\section{International Journal of Current Science Research and Review}

ISSN: 2581-8341

Volume 03 Issue 11 November 2020

DOI: 10.47191/ijesrr/V3-i11-02, Impact Factor: 6.595

IJCSRR@ 2020

www.ijcsrr.org

Table 3. The Result of Residual Normality Test

One-Sample Kolmogorov-Smirnov Test

\begin{tabular}{lll}
\hline $\mathbf{N}$ & & Unstandardized Residual \\
\hline \multirow{2}{*}{ Normal Parameters ${ }^{\mathrm{a}, \mathrm{b}}$} & & 42 \\
\hline \multirow{2}{*}{ Most Extreme Differences } & Mean & $0 \mathrm{E}-7$ \\
\cline { 2 - 3 } & Std. Deviation & 7.06598972 \\
\hline Kolmogorov-Smirnov Z & Absolute & .073 \\
\cline { 2 - 3 } & Positive & .066 \\
\cline { 2 - 3 } & Negative & -.073 \\
\hline Asymp. Sig. (2-tailed) & & .474 \\
\hline
\end{tabular}

a. Test distribution is Normal.

b. Calculated from data.

Table 4. The Result of Linearity Test

ANOVA Table

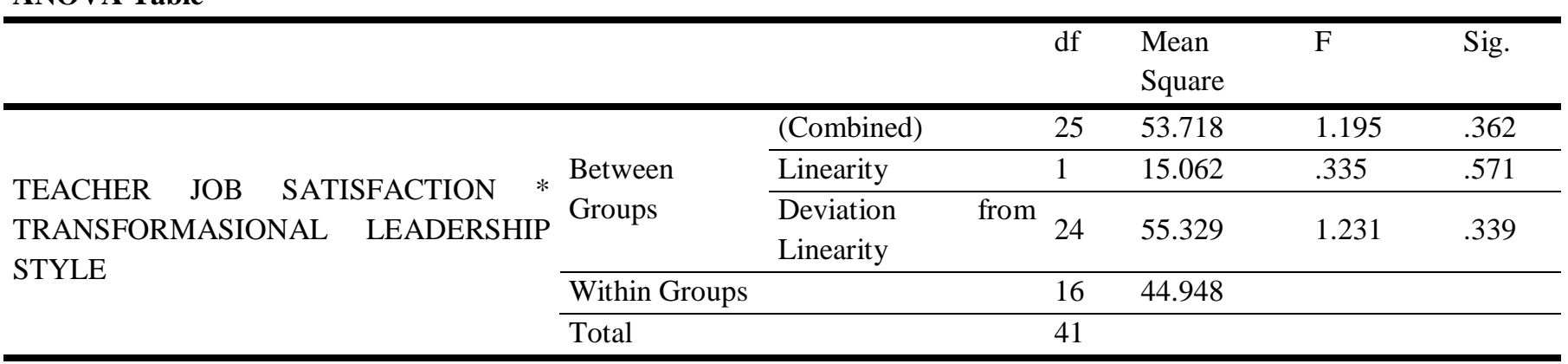

Table 5. The Result of Regression Test

\begin{tabular}{|c|c|c|c|c|c|c|c|}
\hline & \multicolumn{6}{|l|}{ Value of } & \multirow[b]{2}{*}{ Conclusion } \\
\hline & $\begin{array}{l}\text { Pearson } \\
\text { Corelations }\end{array}$ & Sig. & $\mathrm{R}$ & R Square & $\mathrm{T}$ & Sig. & \\
\hline Correlation & 0,089 & 0,295 & & & & & $\mathrm{H}_{0}$ Rejected \\
\hline Model Summary & & & $0,085^{\mathrm{a}}$ & 0,007 & & & $\mathrm{H}_{0}$ Rejected \\
\hline Coefficient & & & & & 0,543 & 0,590 & $\mathrm{H}_{0}$ Rejected \\
\hline
\end{tabular}

Based on the Table 5 above, it can be seen that there is no relationship between transformational leadership style (X) with teacher job satisfaction (Y) as evidenced by the acquisition of a significance value of $0.295>0.05$ so the decision of $\mathrm{H}_{0}$ is rejected. Furthermore, based on the value of $\mathrm{R}$ square, it is known that teacher job satisfaction (Y) is only influenced by $0.7 \%$ by the transformational leadership style (X) of the principal. Then, based on the coefficient table, it is known that there is no significant effect between transformational leadership style $(\mathrm{X})$ on teacher job satisfaction $(\mathrm{X})$ as evidenced by a significance value of $0.590>$ 0.05 and $\mathrm{T}_{\text {value }}<\mathrm{T}_{\text {table }}$ about $0.543<2.021$ so the decision of $\mathrm{H}_{0}$ is rejected.

After knowing that there was no significant relationship and influence between transformational leadership style (X) on teacher job satisfaction (Y), researchers looked at whether other factors such as gender influence the job satisfaction that the teacher has. Therefore, the researcher conducted an Independent Sample T-Test to see the difference in job satisfaction felt by male teachers with female teachers. Based on the table above, it can be seen that there is no significant difference in job satisfaction between male and female teachers with a significance value of $0.090>0.050$ and $\mathrm{T}_{\text {value }}<\mathrm{T}_{\text {table }}$ about $-1.779<2.021$ so the decision of $\mathrm{H}_{0}$ is accepted. 


\section{International Journal of Current Science Research and Review}

ISSN: 2581-8341

Volume 03 Issue 11 November 2020

DOI: 10.47191/ijcsrr/V3-i11-02, Impact Factor: 6.595

IJCSRR@ 2020

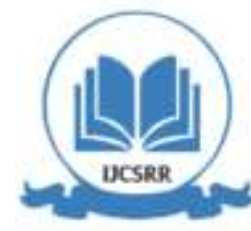

www.ijcsrr.org

Based on the explanation above, it is known that in this study the transformational leadership style possessed by the principal does not have a relationship and a significant effect on teacher job satisfaction. Similarly, gender differences do not have a significant difference in teacher job satisfaction. This result is completely different from the results of previous research, which states that transformational leadership style has a positive and significant effect on teacher job satisfaction (Abdul Wahab, Fuad, Fuzlina, \& Ismail, 2014; Al-Omari \& Sharaah, 2012; Amin et al., 2013; Knab, 2009; Masumoto \& Brown-Welty, 2009; Pepper \& Changing, 2010; Pugh et al., 2011). Then it is not indicated that the transformational leadership style possessed by the principal is evidenced in the calculation results that transformational leadership style only affects teacher job satisfaction by only $0.7 \%$. This is different from the statement of Gkolia and Nazim which revealed that the principal's transformational leadership style plays an important role in increasing teacher job satisfaction (Gkolia et al., 2014; Nazim \& Mahmood, 2018).

The results of this study can have implications for the next study that other factors besides transformational leadership style must be known that can affect teacher job satisfaction. The researcher realizes that the weakness in this study is that the researcher only focuses on the transformational characteristics of the principal as a whole so that in subsequent studies it is expected to analyses one by one the characteristics that exist in transformational leadership style.

\section{CONCLUSION}

Based on research that has been done, it is known that the principal's transformational leadership style does not have a large influence on teacher job satisfaction. Then, there is no difference felt in both male and female teachers in the principal's transformational leadership style towards teacher job satisfaction.

\section{REFERENCES}

1. Abdul Wahab, J., Fuad, M., Fuzlina, C., \& Ismail, H. (2014). Headmasters' transformational leadership and their relationship with teachers' job satisfaction and teachers' commitments. 7(13), 40-48.

2. Adeniji, A.. (2011). Organizational Climate as a Predictor of Employee Job Satisfaction: Evidence from Covenant University. 4(1), 151-166.

3. Al-Omari, A., \& Sharaah, M. (2012). Leadership Readiness among Prospective School Leaders in Jordan. 4(1).

4. Amin, M., Shah, S., Tatlah, I. (2013). Impact of Principals/Directors' Leadership Styles on Job Satisfaction of the Faculty Members: Perceptions of the Faculty Members in a Public University of Punjab, Pakistan. 7(2).

5. Anderson, M. (2017). Transformational Leadership in Education: a Review of Existing Literature. 93(1), 4.

6. Aunga, D. A., \& Masare, O. (2017). Effect of Leadership Styles on Teacher's Performance in Primary Schools of Arusha District Tanzani. 4(4), 42-52.

7. Avolio, B. J., \& Bass, B. (2004). Multifactor Leadership Questionnaire (MLQ). 29.

8. Aydin, A., Sarier, Y., \& Uysal, S. (2013). The Effect of School Principals' Leadership Styles on Teachers' Organizational Commitment and Job Satisfaction. 13(2), 806-811.

9. Bolin, F. (2007). A Study of Teacher Job Satisfaction and Factors That Influence It. 40(5), 47-64.

10. Ch, A. H., Ahmad, S., Malik, M., \& Batool, A. (2017). Principals' Leadership Styles and Teachers' Job Satisfaction: A Correlation Study at Secondary Level. 39(3), 45-56.

11. Eliophotou-Menon, M., \& Ioannou, A. (2016). The Link Between Transformational Leadership and Teachers' Job Satisfaction, Commitment, Motivation to Learn, and Trust in The Leader. 20(3), 12.

12. Eyal, O., \& Roth, G. (2011). Principals' Leadership and Teachers' Motivation: Self-Determination Theory Analysis. 49(3), 256-275.

13. Gkolia, A., Belias, D., \& Koustelios, A. (2014). The Impact of Principals' Transformational Leadership on Teachers' Satisfacti on: Evidence From Greece.

14. Hariri, H., Monypenny, R., \& Prideaux, M. (2012). Principalship in an Indonesian School Context: Can Principal DecisionMaking Styles Significantly Predict Teacher Job Satisfaction? , 32(5), 453-471.

15. Hui, H., Jenatabadi, H. S., Ismail, B., Azina, N., Radzi, W. M., \& Jasimah, C. W. (2014). Principal's Leadership Style And Teacher Job Satisfaction: A Case Study In China.

16. Karabina, M. (2016). The Impact Of Leadership Style To The Teachers'job Saticfaction. 
ISSN: 2581-8341

Volume 03 Issue 11 November 2020

DOI: 10.47191/ijcsrr/V3-i11-02, Impact Factor: 6.595

IJCSRR @ 2020

www.ijcsrr.org

17. Kimathi, M. K. (2017). Influence of Principals' Leadership Styles on Teachers' Job Satisfaction in Public Secondary Schools in Meru South Sub-County, Tharaka Nithi County, Kenya. 5(11), 28-34.

18. Knab, D. (2009). A comparison of the leadership practices of principals of high schools that work schools as measured by the leadership practices inventory. 7(2), 2.

19. Kothari, C. R. (2004). Research methodology: Methods and techniques: New Age International.

20. Leykin, Y., \& DeRubeis, R. (2010). Decision-making styles and depressive symptomatology: Development of the Decision Styles Questionnaire. 5(7), 506.

21. Mahdinezhad, M., \& Suandi, B. (2013). Transformational, Transactional Leadership Styles and Job Performance of Academic Leaders. 6(11), 29-34.

22. Masumoto, M., \& Brown-Welty, S. (2009). Case study of leadership practices and school-community interrelationships in high-performing, high-poverty, rural California high schools. 24(1), 1.

23. Musringudin, M., Akbar, M., \& Karnati, N. (2017). The Effect Of Organizational Justice, Job Satisfaction, And Organizational Commitment On Organizational Citizenship Behavior (Ocb) Of The Principles. 4(2), 155-165.

24. Nadarasa, T., \& Thuraisingam, R. (2014). The Inflence Of Principals'leadership Styles On School Teachers'job Satisfaction-Study Of Secondry School In Jaffna District. 4(1), 1-7.

25. Nazim, F., \& Mahmood, A. (2018). A Study of relationship between leadership style and Job Satisfaction. 6(1), $165-181$.

26. Nyenyembe, F. W., Maslowski, R., Nimrod, B. S., \& Peter, L. (2016). Leadership Styles and Teachers' Job Satisfaction in Tanzanian Public Secondary Schools. 4(5), 980-988.

27. Omeke Faith, C., \& Onah Kenneth, A. (2011). The influence of principals' leadership styles on secondary school teachers' job satisfaction.

28. Pepper, K. J. P., \& Changing. (2010). Effective principals skillfully balance leadership styles to facilitate student success: A focus for the reauthorization of ESEA. 41, 42-56.

29. Pieterse, A. N., Van Knippenberg, D., Schippers, M., \& Stam, D. (2010). Transformational and transactional leadership and innovative behavior: The moderating role of psychological empowerment. 31(4), 609-623.

30. Pugh, A. G., Fillingim, J. G., Blackbourn, J., \& Thomas, C. (2011). Faculty validation of the leadership practices inventory with secondary school principals.

31. Raziq, A., \& Maulabakhsh, R. (2015). Impact of Working Environment on Job Satisfaction. Procedia Economics and Finance, 23, 717-725. doi:10.1016/s2212-5671(15)00524-9

32. Shamaki, E. (2015). Influence of Leadership Style on Teacher's Job Productivity in Public Secondary Schools in Taraba State, Nigeria. 6(10), 200-203.

33. Spector, P. E. (1994). Job satisfaction survey, JSS. 20, 2002.

34. Voon, M. L., Lo, M. C., Ngui, K. S., \& Ayob, N. B. (2011). The influence of leadership styles on employees' job satisfaction in public sector organizations in Malaysia. 2(1), 24-32.

35. Wachira, F. M., GIitumu, M., \& Mbugua, Z. (2017). Effect of Principals' Leadership Styles on Teachers' Job Performance in Public Secondary Schools in Kieni West Sub-County. 6(8), 72-86.

36. Wang, G., Oh, I.-S., Courtright, S. H., Colbert, A. (2011). Transformational leadership and performance across criteria and levels: A meta-analytic review of 25 years of research. 36(2), 223-270.

37. Wilson, G. (2017). Principals' Leadership Style and Staff Job Performance in Selected Secondary Schools in Emohua Local Government Area of Rivers State, Nigeria. 11(3), 115-131. 